\title{
PMP22 wt Allele
}

National Cancer Institute

\section{Source}

National Cancer Institute. PMP22 wt Allele. NCI Thesaurus. Code C75901.

Human PMP22 wild-type allele is located within 17p12-p11.2 and is approximately $36 \mathrm{~kb}$ in length. This allele, which encodes peripheral myelin protein 22 , plays a role in the modulation of the structure of myelin. Mutation of the gene is associated with CharcotMarie-Tooth disease Types IA and IE, Dejerine-Sottas syndrome, inflammatory demyelinating polyneuropathy and hereditary neuropathy with liability to pressure palsies. 